\title{
Comparison of Citrus Sector Competitiveness between Turkey and EU-15 Member Countries
}

\author{
Halil Fidan ${ }^{1}$ \\ Ankara University, Faculty of Agriculture, Department of Agricultural \\ Economics, Diskapi, Ankara 06110, Turkey
}

Additional index words. citrus, competitiveness, EU, revealed competitive advantage, Turkey

\begin{abstract}
A missing component of existing research on Turkey's citrus products is examination of their revealed comparative advantage (RCA). Such information would enable a comparison of Turkey and EU-15 countries in regard to citrus sector competitiveness. Therefore, this study calculates the RCA for citrus products and explores their competitiveness as well as components of their competitive performance. RCAs for citrus trade performances of both EU-15 countries and Turkey are examined, and the sources of export performance and competitiveness are newly presented. The results indicate that the principle of comparative advantage is a useful tool for understanding the future of citrus agriculture in EU-15 countries and Turkey. In line with the assumption that the dynamics of comparative advantage have become increasingly transparent as citrus markets have become less fettered by government trade, this study uses an RCA index to investigate the patterns of comparative advantage in the EU-15 countries and Turkey in regard to citrus exports. Since the beginning of the Entry Price System in the European Union in 1995, significant changes in citrus export performance have occurred. The RCA index of the Turkish citrus sector within EU-15 countries $\left(\mathrm{RCA}_{\mathrm{e}}\right)$ shows that Greece, Spain, Italy, and Portugal are Turkey's main competitors. The $\mathrm{RCA}_{\mathrm{e}}$ index and relative trade advantage index indicate that Turkey's competitive power is greater than those of Spain, Italy, Greece, and Portugal in lemon/ limes and grapefruit exports.
\end{abstract}

Turkey applied for membership to the European Economic Community in 1959, 1 year after the enforcement of the Treaty of Rome. The Ankara Agreement (EC, 1973) in 1963 and the Additional Protocol in 1970 identified the modalities and calendars ensuring future entry to the Customs Union and confirming the ultimate aim of full membership (Carlqvist, 2008; Furtun, 2004).

Turkey has been in the Customs Union of the European Union (EU) since 31 Dec. 1995 (EC, 1996). In Dec. 1997, the Luxemburg European Council confirmed Turkey's eligibility for accession into the EU with the future accession decision to be judged on the same criteria as used for other applicant states (EC, 2000). The accession procedure requires Turkey's preparation and commitment to bringing itself closer to the EU in every aspect (Kayalar, 2006).

During preparation for the accession process, a particularly important economic issue is the free movement of goods, particularly products of agricultural origin. Decision No. 1/95 of the EC-Turkey Association Council on implementing the final phase of the Customs Union excluded agricultural products from eliminations of customs duties, quantitative restrictions, and measures with

Received for publication 7 Oct. 2008. Accepted for publication 8 Nov. 2008.

${ }^{1}$ To whom reprint requests should be addressed; e-mail fidan@agri.ankara.edu.tr. equivalent effects. The Association Council allowed special provisions for agricultural products and noted that an additional period is required to implement the conditions necessary for free movement of agricultural products (Akgüngör et al., 2002).

Citrus production and consumption have experienced strong growth in the EU and Turkey since the mid-1980s. Orange, grapefruit, mandarin, lemon, and lime production has expanded rapidly. Larger production levels have enabled higher levels of total, as well as per capita, citrus consumption. Even faster growth has occurred in processed citrus products as improvements in transportation and packaging have lowered costs and improved quality (DEFRA, 2001).

However, with rapid output expansion and slower demand growth for some citrus products, prices have decreased for both fresh and processed citrus products. As a result, the rate of new tree plantings has slowed. Hence, projected growth rates in production and consumption over the next 10 years are expected to be lower than those over the past 10 years. Meanwhile, Turkey, one of the largest citrus-producing countries, has struggled to join the EU.

The EU has always been one of the world's largest importers of citrus. Even the accession of some significant net exporters of citrus such as Greece in 1980 and Portugal and Spain in 1986 did not fundamentally alter this situation. EU policies for the citrus sector have changed in a number of ways in recent years. The Uruguay Round Agreement on Agriculture required the EU to reduce its tariffs and adjust the former reference price system in accordance with "tariffication." A new entry price system resulted and has been used since 1995. In addition, the World Trade Organization (WTO) agreed to a Special Safeguard Clause for products subject to tariffication, and the EU has introduced related changes into its trade regime for citrus products. Moreover, a separate WTO agreement specifies new rules on sanitary and phytosanitary measures (EC, 1998).

EUROSTAT and Food and Agriculture Organization data show that the four largest citrus-producing EU-15 countries, namely Spain, Greece, Italy, and Portugal, will continue to produce citrus. With the growth of Clementine consumption, Spain is expected to expand production of mandarin oranges. Italy will also realize expanded production and consumption of Satsuma oranges. Additionally, France is expected to continue to expand its citrus production, although at a slower rate. Other EU countries such as Austria, Belgium-Luxembourg, Denmark, Finland, Germany, Ireland, The Netherlands, Sweden, and the United Kingdom are important citrus-importing countries. Therefore, EU-15 may become an important market for citrus production.

Turkey's preparations to join the EU have led to partial trade liberalization and increased competitive pressures (Allen, 2000). However, although Turkey is an important citrus producer, there is no information about its competitiveness in comparison with EU15 member countries.

The main objective of this article is to understand Turkey's competitiveness in citrus exports in the EU market in comparison with EU-15 countries. The goal is to develop a balanced overview of the citrus markets of Turkey and EU countries. Consequences for both Turkey and EU-15 countries are explored based on available data on market and competitive situations with emphasis on real comparative advantage (RCA) processes and market developments.

Specifically, this study attempts to answer the following questions: 1 ) What are the main problems with respect to citrus markets involved with the competitiveness of citrus products? 2) What is the citrus situation of Turkey and its competitiveness in the citrus sector? 3) What is the competitive performance of the Turkish citrus sector? 4) What are the main differences between the RCAs of EU-15 countries and Turkey? 5) What are the RCA positions of Turkey and EU-15 countries?

The analysis is based on the concept of RCA using Turkey-EU-15 trade data for the 1990s. This study will be informative for both researchers and policymakers involved in citrus policies in Turkey and the EU-15 countries.

\section{Material and Methods}

This study uses export and import data obtained from Turkey's State Statistics 
Office (http://www.die.gov.tr), the Food and Agriculture Organization (www.fao.org), and the Statistical Office of the European Commission (Eurostat; http://europa.eu.int/ comm/eurostat/) for the following commodity groups:

- Oranges and mandarins, including fresh oranges and mandarins, orange and mandarin juice, and concentrated orange and mandarin juice;

- Lemons and limes, including fresh lemons and limes, lemon and lime juice, and concentrated lemon and lime juice;

- Grapefruits, including fresh grapefruit, grapefruit juice, and concentrated grapefruit juice; and

- Other citrus products such as kiwis, mangos, and tangerines, including fresh other citrus, other citrus juice, and concentrated other citrus juice (Hunt and Koppel, 2006).

RCAs and relative trade advantages (RTAs) are calculated for these commodity groups. The data set on citrus exports and imports covers the period of 1990 to 2003.

The concept of RCA is grounded in traditional international trade theory and is based on export specialization. Although variations have been proposed and tested, the original RCA index was formulated by Balassa $(1965,1977,1979,1986)$ and Fertö and Humbord (2001). Because the idea revolves around the concept of comparative advantage, a measure of comparative advantage is required. Although several alternative measures have been suggested (Masters, 1995), one of the most detailed and useful is the concept of RCA, particularly the popular method of examining trade liberalization and RCA. RCA is based on export performance and observed trade patterns and measures a country's exports of a commodity relative to its total exports and to the corresponding export performance of a set of countries. The RCA index is calculated as:

$$
R C A=\frac{x_{i j}}{x_{w j}} / \frac{\sum_{j} x_{i}}{\sum_{j} x_{w}}
$$

For this study, $x$ represents citrus exports, $i$ is a country, $j$ is a citrus product, and $w$ is a set of countries. RCA greater than 1 indicates that the country has a comparative advantage exporting the good but not importing that good (Richardson and Zhang, 1999).

The RCA for citrus is given as:

$$
\begin{array}{r}
R C A_{e}=\frac{x_{i j}}{x_{c j}} / \frac{\sum_{j} x_{i}}{\sum_{j} x_{c}} \text { for export and } \\
R C A_{i}=\frac{m_{i j}}{m_{c j}} / \frac{\sum_{j} m_{i}}{\sum_{j} m_{c}} \text { for import }
\end{array}
$$

where $x$ represents citrus exports, $i$ is a country, $j$ is citrus variety, $m$ explains citrus imports, and $c$ is a set of countries. Here, the individual countries examined are Turkey as well as each EU-15 country (with Belgium and Luxemburg combined); the set of coun- tries includes the EU-15 countries and Turkey. The groups of citrus products also separately include grapefruits, lemons, limes, oranges, mandarins, and other citrus.

The RTA (Vollrath, 1991) offers an alternative way of measuring a country's RCA. The RTA index shows the net trade advantage or disadvantage as a comprehensive measure of competitiveness. This index is given by the difference between the revealed export advantage $\left(\mathrm{RCA}_{\mathrm{e}}\right)$ and the relative import penetration index, the Balassa index. If RTA is greater than 0 , then trade advantage is revealed:

$$
R T A=\left(\frac{x_{i j}}{x_{c j}} / \frac{\sum_{j} x_{i}}{\sum_{j} x_{c}}\right)-\left(\frac{m_{i j}}{m_{c j}} / \frac{\sum_{j} m_{i}}{\sum_{j} m_{c}}\right)
$$

In this study, data from 1990 to 2003 were analyzed statistically using the EXCEL computer program (Callaert, 1999). The mean, $\mathrm{SD}$, minimum and maximum values, and $\mathrm{CV}$ of each country were determined (Snedecor and Cochran, 1989) to show the following.

Mean. The mean (or average) is a simple measure of the central tendency of the RCA and RTA:

$$
\begin{aligned}
\text { mean }= & \text { sum of all RCA and RTA data } \\
& \div \text { sample size }(\text { often called } \mathrm{n})
\end{aligned}
$$

$S D$. The SD of RCA and RTA values is the square root of the variance. Therefore, it reflects both the deviation from the mean and the frequency of this deviation:

$$
\mathrm{SD}=\mathrm{sq} \operatorname{root}(\text { variance })
$$

$C V$. This is the ratio of the SD to the mean. The CV describes the magnitude of sample values and the variation within them:

$$
\mathrm{CV}=\frac{\mathrm{SD}}{\text { Mean }} \cdot 100
$$

\section{Results and Discussion}

This study focuses on Turkey's citrus trade with the member states of EU-15. In calculating RCA and RTA, all trade flows refer to those between Turkey and the EU-15 countries.

Table 1 displays the summary statistics (mean, SD, minimum, maximum, and $\mathrm{CV}$ ) for the $\mathrm{RCA}_{\mathrm{e}}$ indices for Turkish citrus exports to the EU-15 countries. According to the mean $\mathrm{RCA}_{\mathrm{e}}$ calculated from the period 1990 to 2003, $\mathrm{RCA}_{\mathrm{e}}$ values for oranges and mandarins are higher in Denmark, Finland, Greece, Portugal, Spain, and Sweden compared with other countries. Those countries thus have large exports of oranges and mandarins and are competitive with the other countries. For oranges and mandarins, the main competitors of Greece, Portugal, and Spain are Denmark, Finland, and Sweden (re-export countries). Greece and Spain have a transport cost advantage over other EU-15 markets and face less competition from the EU-15 market in the orange and mandarin market than in the grapefruit market. For Turkey, the high CV values for these product groups indicate unstable indices over the past two decades. Moreover, $\mathrm{RCA}_{\mathrm{e}}$ index values show stronger variability for Denmark, Finland, Greece, Portugal, Spain, and Sweden than for Turkey.

In the second line of Table 1 , the $\mathrm{RCA}_{\mathrm{e}}$ values of lemons and limes are higher for Turkey than for the EU-15 countries. Lemons and limes are clearly the dominant exports of Turkey, which is competitive with the EU-15 countries. The $\mathrm{RCA}_{\mathrm{e}}$ for Turkish lemons and limes exhibited a noticeable stable trend during the past two decades (except in regard to Italy and Spain), whereas the $\mathrm{RCA}_{\mathrm{e}}$ values for other EU-15 countries generally display dynamic trends. The low $\mathrm{CV}$ values for these product groups show that the indices were stable over the past two decades. Moreover, the variability in $\mathrm{RCA}_{\mathrm{e}}$ index values is stronger for the other countries than for Turkey.

For grapefruit, Turkey had a mean $\mathrm{RCA}_{\mathrm{e}}$ of 2.335 over the past two decades, which is higher than that of EU-15 countries with the exception of The Netherlands. The Netherlands does not produce grapefruit, but rather re-exports this fruit. Thus, Turkey also has a revealed comparative advantage. The $\mathrm{CV}$ values for Turkish grapefruit are less than those of the EU-15 countries. Other citrus product groups that did not reveal a comparative advantage are oranges, mandarins, and other citrus products. The CV values for these groups are all higher, except for Portugal.

The mean $\mathrm{RCA}_{\mathrm{e}}$ of other citrus products is dominated by Italy, Sweden, and the United Kingdom. Together, these countries have a high SD in the $\mathrm{RCA}_{\mathrm{e}}$ data, which shows that they have little stability for other citrus trade.

Table 1 shows that the $\mathrm{RCA}_{\mathrm{e}}$ indices (especially for lemons and limes and for grapefruit) for the major EU-15 export countries (Spain, Italy, Greece) have increased significantly since the beginning of the Entry Price System (Göetz and Grethe, 2007). This suggests that conditions in the postliberalization period have had an adverse effect on the comparative advantage of the majority of EU-15 countries (EC, 2001).

Determining the level of Turkish trade competition in the EU market requires calculation of the RTA for some citrus product categories covering virtually all trade in Turkish exports to the EU-15 market. The shares of these product groups and Turkish exports to the EU-15 countries have also been calculated to grasp the relative importance of citrus product trade competition within total citrus trade. Table 2 summarizes the results. If RTA is greater than 0 , then a trade advantage is revealed.

In terms of average values for the past two decades, Turkey has a trade advantage (RTA greater than 0) for lemons, limes, and grapefruit in the EU-15 market. Table 2 shows the RTA values for each product category averaged for 1990 to 2003 and how RTA varies by citrus product group in specific countries. On average, compared with EU-15 countries, Turkey has a comparative trade advantage in 
Table 1. Revealed comparative advantages of Turkey with respect to EU-15 countries $\left(\mathrm{RCA}_{\mathrm{e}}\right)$.

\begin{tabular}{|c|c|c|c|c|c|}
\hline & Mean & SD & $\begin{array}{c}\text { Variation } \\
\text { coefficient }\end{array}$ & Minimum & Maximum \\
\hline \multicolumn{6}{|l|}{ Orange and mandarin } \\
\hline Austria & 0.864 & 0.254 & 29.365 & 0.278 & 1.101 \\
\hline Belgium-Luxemburg & 0.960 & 0.123 & 12.777 & 0.741 & 1.073 \\
\hline Denmark & 1.173 & 0.049 & 4.219 & 1.129 & 1.294 \\
\hline Finland & 1.116 & 0.119 & 10.662 & 0.818 & 1.379 \\
\hline France & 0.972 & 0.101 & 10.429 & 0.712 & 1.088 \\
\hline Germany & 1.029 & 0.144 & 13.948 & 0.764 & 1.134 \\
\hline Greece & 1.118 & 0.143 & 12.764 & 0.983 & 1.382 \\
\hline Ireland & 1.008 & 0.177 & 17.603 & 0.602 & 1.186 \\
\hline Italy & 0.987 & 0.119 & 12.071 & 0.754 & 1.179 \\
\hline The Netherlands & 0.898 & 0.066 & 7.405 & 0.809 & 1.040 \\
\hline Portugal & 1.044 & 0.149 & 14.305 & 0.785 & 1.227 \\
\hline Spain & 1.015 & 0.025 & 2.447 & 0.986 & 1.068 \\
\hline Sweden & 1.054 & 0.097 & 9.239 & 0.818 & 1.215 \\
\hline United Kingdom & 0.947 & 0.077 & 8.161 & 0.773 & 1.051 \\
\hline Turkey ${ }^{z}$ & 0.658 & 0.090 & 13.621 & 0.539 & 0.845 \\
\hline \multicolumn{6}{|l|}{ Lemons and limes } \\
\hline Austria & 0.514 & 0.306 & 59.533 & 0.265 & 1.403 \\
\hline Belgium-Luxemburg & 0.241 & 0.216 & 89.506 & 0.060 & 0.651 \\
\hline Denmark & 0.133 & 0.178 & 133.706 & 0.011 & 0.537 \\
\hline Finland & 0.293 & 0.405 & 138.361 & 0.022 & 1.497 \\
\hline France & 0.498 & 0.260 & 52.291 & 0.223 & 1.087 \\
\hline Germany & 0.240 & 0.336 & 140.047 & 0.030 & 1.047 \\
\hline Greece & 1.006 & 0.485 & 48.206 & 0.174 & 1.779 \\
\hline Ireland & 0.153 & 0.162 & 105.730 & 0.001 & 0.468 \\
\hline Italy & 1.694 & 0.566 & 33.425 & 0.685 & 2.409 \\
\hline The Netherlands & 0.650 & 0.160 & 24.573 & 0.348 & 0.853 \\
\hline Portugal & 0.850 & 1.084 & 127.481 & 0.023 & 3.941 \\
\hline Spain & 1.390 & 0.304 & 21.873 & 1.051 & 1.936 \\
\hline Sweden & 0.455 & 0.317 & 69.608 & 0.022 & 1.196 \\
\hline United Kingdom & 0.435 & 0.128 & 29.461 & 0.275 & 0.683 \\
\hline Turkey $^{z}$ & 3.268 & 1.263 & 38.642 & 1.177 & 4.971 \\
\hline \multicolumn{6}{|l|}{ Grapefruit } \\
\hline Austria & 2.551 & 2.514 & 98.557 & 0.562 & 8.924 \\
\hline Belgium-Luxemburg & 2.605 & 1.162 & 44.630 & 1.188 & 4.528 \\
\hline Denmark & 0.275 & 0.252 & 91.605 & 0.121 & 1.023 \\
\hline Finland & 0.453 & 0.331 & 73.177 & 0.000 & 1.108 \\
\hline France & 2.115 & 0.705 & 33.340 & 1.382 & 3.366 \\
\hline Germany & 1.373 & 1.277 & 93.012 & 0.238 & 4.104 \\
\hline Greece & 0.073 & 0.022 & 30.399 & 0.039 & 0.117 \\
\hline Ireland & 0.725 & 0.242 & 33.322 & 0.223 & 1.106 \\
\hline Italy & 0.349 & 0.156 & 44.705 & 0.175 & 0.638 \\
\hline The Netherlands & 2.914 & 0.529 & 18.161 & 2.445 & 4.087 \\
\hline Portugal & 0.711 & 1.290 & 181.549 & 0.001 & 4.499 \\
\hline Spain & 0.159 & 0.030 & 18.983 & 0.115 & 0.218 \\
\hline Sweden & 1.059 & 0.861 & 81.249 & 0.153 & 3.217 \\
\hline United Kingdom & 2.379 & 1.145 & 48.134 & 1.236 & 5.080 \\
\hline Turkey ${ }^{z}$ & 2.335 & 0.496 & 21.229 & 1.876 & 3.248 \\
\hline \multicolumn{6}{|l|}{ Other citrus } \\
\hline Austria & 3.753 & 8.666 & 230.927 & 0.000 & 31.934 \\
\hline Belgium-Luxemburg & 0.403 & 1.152 & 285.564 & 0.003 & 4.388 \\
\hline Denmark & 0.222 & 0.557 & 250.577 & 0.000 & 1.649 \\
\hline Finland & 2.803 & 9.920 & 353.890 & 0.000 & 37.246 \\
\hline France & 2.666 & 5.945 & 222.955 & 0.061 & 18.742 \\
\hline Germany & 2.240 & 6.006 & 268.174 & 0.012 & 23.021 \\
\hline Greece & 0.417 & 0.651 & 156.188 & 0.006 & 2.519 \\
\hline Ireland & 4.620 & 2.801 & 60.625 & 0.000 & 10.133 \\
\hline Italy & 7.996 & 5.624 & 70.337 & 0.078 & 16.972 \\
\hline The Netherlands & 0.651 & 0.554 & 85.065 & 0.026 & 1.800 \\
\hline Portugal & 0.016 & 0.059 & 374.166 & 0.000 & 0.222 \\
\hline Spain & 0.077 & 0.117 & 151.628 & 0.001 & 0.434 \\
\hline Sweden & 6.863 & 6.420 & 93.545 & 0.609 & 17.024 \\
\hline United Kingdom & 7.839 & 7.365 & 93.958 & 0.129 & 23.185 \\
\hline Turkey $^{z}$ & 0.961 & 1.556 & 161.970 & 0.000 & 5.852 \\
\hline
\end{tabular}

${ }^{2} \mathrm{EU}$ candidate country.

$\mathrm{RCA}_{\mathrm{e}}=$ difference between the revealed export advantage.

two citrus product groups (lemons and limes, grapefruit).

These results suggest that further trade policy reforms have weakened competitiveness in Turkish citrus exports. In particular,
Turkey's desire to join the Customs Union has put pressure on Turkey to liberalize its markets for foreign trade. On the export side, these changes have forced enterprises to compete in EU markets with much less help from the government. As a result, the composition of Turkey's exports has evolved increasingly along the line of the country's comparative advantage. However, Turkey's comparative advantage in lemons and limes as well as grapefruit remains very strong because of its climate advantage. Between 1990 and 2003, the $\mathrm{RCA}_{\mathrm{e}}$ index increased from 1.117 to 4.971 for lemons and limes and from 1.876 to 3.248 for grapefruit. In other words, Turkey moved from a comparative disadvantage to a comparative advantage in lemons and limes as well as grapefruit in contrast to the orange and mandarin segment and other citrus markets. These results show that, together with Turkey's climate advantage for some fruits, the country has also experienced a tendency toward decreasing competitiveness in its orange and mandarin exports, which is reflected in its comparative advantage (DPT, 1997). The major disadvantages also imposed from citrus trade side are the high production cost, labor cost, and transport costs, lack of production-infrastructure, technology, and so on, which we have not discussed in this study.

Tables 1 and 2 present the calculated citrus $\mathrm{RCA}_{\mathrm{e}}$ and RTA index values for 14 countries (Belgium and Luxemburg are combined) and Turkey. Citrus (especially lemons and grapefruit) is clearly a dominant export product of Turkey relative to the EU-15 countries. The $\mathrm{RCA}_{\mathrm{e}}$ and RTA for Turkey exhibit a noticeable upward trend during the past two decades, whereas the $\mathrm{RCA}_{\mathrm{e}}$ and RTA values for the EU-15 countries generally display prominent downward trends. Moreover, the variability in the $\mathrm{RCA}_{\mathrm{e}}$ and RTA index values is stronger for other EU-15 countries compared with Turkey, particularly during earlier years.

Spain, Italy, and Greece are main citrus producers. Excluding Turkey, the EU-15 countries within the Mediterranean region show a strong positive correlation with citrus production (perhaps as a result of similar climactic circumstances). When Turkey, Spain, Italy, and Greece are excluded from the analysis, $\mathrm{RCA}_{\mathrm{e}}$ and RTA pairings are positively correlated for some citrus products (Malorgio and Hertzberg, 2007).

Turkish orange and mandarin exports have declined significantly since the beginning of the Entry Price System in the EU-15 market. This suggests that conditions in the last two decades have adversely affected the comparative advantage of Turkey for orange and mandarins. This may be because Spain has begun to produce more oranges, and Italy increased its production of mandarins (especially Satsuma; Argilos, 1999). For oranges and mandarins, although the Turkish $\mathrm{RCA}_{\mathrm{e}}$ values have not changed significantly, the $\mathrm{RCA}_{\mathrm{e}}$ values of Spain and Greece have increased substantially since 1990 (DPT, 2000).

Turkey's success is therefore not only defined by revealed comparative advantages, but is also the product of a favorable environment conducive to citrus production. 
Table 2. Revealed trade advantages of Turkey with respect to EU-15 countries (RTA greater than 0 ).

\begin{tabular}{|c|c|c|c|c|c|}
\hline & Mean & SD & $\begin{array}{c}\text { Variation } \\
\text { coefficient }\end{array}$ & Minimum & Maximum \\
\hline \multicolumn{6}{|l|}{ Orange and mandarin } \\
\hline Austria & -0.069 & 0.236 & -344.458 & -0.647 & 0.073 \\
\hline Belgium-Luxemburg & -0.052 & 0.086 & -167.169 & -0.237 & 0.022 \\
\hline Denmark & 0.104 & 0.067 & 64.631 & 0.035 & 0.211 \\
\hline Finland & -0.002 & 0.139 & $-8,836.582$ & -0.395 & 0.185 \\
\hline France & 0.013 & 0.122 & 973.200 & -0.287 & 0.148 \\
\hline Germany & 0.013 & 0.189 & $1,504.986$ & -0.336 & 0.127 \\
\hline Greece & 0.261 & 0.419 & 160.255 & -0.056 & 1.181 \\
\hline Ireland & 0.033 & 0.181 & 547.629 & -0.537 & 0.212 \\
\hline Italy & 0.342 & 0.134 & 39.073 & 0.161 & 0.545 \\
\hline The Netherlands & -0.058 & 0.043 & -72.796 & -0.137 & -0.004 \\
\hline Portugal & 0.057 & 0.153 & 267.939 & -0.278 & 0.256 \\
\hline Spain & -0.035 & 0.073 & -209.986 & -0.154 & 0.071 \\
\hline Sweden & -0.058 & 0.125 & -215.134 & -0.396 & 0.073 \\
\hline United Kingdom & -0.061 & 0.081 & -132.788 & -0.255 & 0.045 \\
\hline Turkey $^{2}$ & -0.221 & 0.233 & -105.338 & -0.553 & 0.574 \\
\hline \multicolumn{6}{|l|}{ Lemons and limes } \\
\hline Austria & -1.357 & 0.494 & -36.394 & -2.085 & -0.558 \\
\hline Belgium-Luxemburg & -0.274 & 0.113 & -41.072 & -0.466 & -0.088 \\
\hline Denmark & -0.910 & 0.323 & -35.509 & -1.349 & -0.281 \\
\hline Finland & -0.272 & 0.389 & -143.173 & -0.524 & 0.979 \\
\hline France & -0.575 & 0.341 & -59.350 & -0.931 & 0.195 \\
\hline Germany & -0.920 & 0.447 & -48.620 & -1.224 & 0.159 \\
\hline Greece & -1.991 & 1.636 & -82.191 & -4.678 & 0.576 \\
\hline Ireland & -0.736 & 0.614 & -83.421 & -2.680 & -0.113 \\
\hline Italy & -0.380 & 1.403 & -369.567 & -2.236 & 2.219 \\
\hline The Netherlands & -0.121 & 0.116 & -96.337 & -0.275 & 0.095 \\
\hline Portugal & -0.700 & 1.069 & -152.697 & -2.619 & 2.032 \\
\hline Spain & -0.151 & 1.015 & -673.620 & -1.835 & 1.314 \\
\hline Sweden & -0.356 & 0.380 & -106.695 & -0.845 & 0.535 \\
\hline United Kingdom & -0.467 & 0.152 & -32.497 & -0.634 & -0.182 \\
\hline Turkey $^{z}$ & 0.955 & 3.117 & 326.467 & -7.550 & 4.273 \\
\hline \multicolumn{6}{|l|}{ Grapefruit } \\
\hline Austria & 2.033 & 2.297 & 112.999 & 0.234 & 8.011 \\
\hline Belgium-Luxemburg & 1.572 & 0.901 & 57.313 & 0.463 & 2.960 \\
\hline Denmark & -0.232 & 0.447 & -193.006 & -1.596 & 0.422 \\
\hline Finland & 0.032 & 0.351 & 1.097 .618 & -0.695 & 0.736 \\
\hline France & 0.870 & 0.688 & 79.141 & 0.147 & 2.192 \\
\hline Germany & 0.746 & 1.261 & 168.997 & -0.357 & 3.391 \\
\hline Greece & -0.395 & 0.102 & -25.910 & -0.557 & -0.213 \\
\hline Ireland & -0.025 & 0.296 & -1.162 .755 & -0.667 & 0.511 \\
\hline Italy & -3.088 & 2.213 & -71.667 & -7.506 & -0.505 \\
\hline The Netherlands & 1.534 & 0.460 & 30.014 & 1.081 & 2.755 \\
\hline Portugal & -0.022 & 0.459 & $-2,081.789$ & -0.757 & 0.671 \\
\hline Spain & -0.160 & 0.109 & -67.819 & -0.355 & 0.007 \\
\hline Sweden & 0.677 & 0.842 & 124.475 & -0.357 & 2.701 \\
\hline United Kingdom & 1.500 & 1.031 & 68.733 & 0.383 & 3.962 \\
\hline Turkey $^{z}$ & 1.059 & 1.366 & 129.088 & -1.755 & 2.663 \\
\hline \multicolumn{6}{|l|}{ Other citrus } \\
\hline Austria & 1.828 & 8.499 & 464.906 & -3.054 & 30.991 \\
\hline Belgium-Luxemburg & -0.140 & 0.308 & -219.409 & -1.168 & 0.129 \\
\hline Denmark & -0.364 & 0.637 & -174.962 & -1.890 & 0.031 \\
\hline Finland & -0.819 & 9.527 & $-1,162.655$ & -19.112 & 23.596 \\
\hline France & 2.609 & 5.956 & 228.275 & 0.044 & 18.706 \\
\hline Germany & 0.495 & 6.548 & $1,323.762$ & -2.439 & 23.001 \\
\hline Greece & -8.402 & 20.691 & -246.254 & -67.462 & 1.805 \\
\hline Ireland & -0.213 & 6.001 & $-2,822.883$ & -12.845 & 7.906 \\
\hline Italy & 5.807 & 6.346 & 109.286 & -6.904 & 16.531 \\
\hline The Netherlands & 0.499 & 0.502 & 100.513 & -0.069 & 1.687 \\
\hline Portugal & -0.150 & 0.337 & -225.411 & -1.201 & 0.222 \\
\hline Spain & -1.244 & 1.947 & -156.519 & -5.098 & 0.067 \\
\hline Sweden & 2.964 & 7.135 & 240.754 & -11.483 & 16.119 \\
\hline United Kingdom & 6.321 & 7.122 & 112.678 & 0.110 & 21.507 \\
\hline Turkey $^{z}$ & -3.075 & 11.444 & -372.132 & -41.691 & 5.817 \\
\hline
\end{tabular}

${ }^{\mathrm{z}} \mathrm{EU}$ candidate country.

$\mathrm{RTA}=$ relative trade advantage.

\section{Conclusions}

The aim of this study was to understand the Turkish citrus sector in the EU-15 citrus market. Main problems faced by Turkey are decline in Turkey's share of the citrus market. These problems are hardly unique to Turkey. Several citrus-producing countries of the EU-15 have faced similar circumstances and have managed to maintain their pre-eminence in the EU-15 market.

This article has attempted to explain success in citrus production and trade by applying comparative advantage theory. Building on the existing literature, an index of the revealed comparative advantage $\left(\mathrm{RCA}_{\mathrm{e}}\right)$ was used to measure export performance as a reflection of comparative and competitive advantage. This index was used to identify particular patterns among EU-15 countries and Turkey.

The resulting $\mathrm{RCA}_{\mathrm{e}}$ index values for citrus-producing countries tends to be positively correlated, whereas countries not producing citrus tend to be negatively correlated. This appears to confirm a significant differentiation between production and re-export in citrus markets. The $\mathrm{RCA}_{\mathrm{e}}$ index values for countries within the same region tend to be similar, suggesting similar regional influences on $\mathrm{RCA}_{\mathrm{e}}$ index values (e.g., climate). The $\mathrm{RCA}_{\mathrm{e}}$ index values appear to have changed significantly since the start of the EU Entry Price System. For most countries analyzed here, liberalization seems to have had a detrimental effect on export performance.

The findings show that Turkey's citrus product exports to the EU-15 market have grown, likely as a result of Turkey's favorable climate, which is relatively better than those of other countries for citrus products (except for Spain, Greece, and Italy). The RCA analysis shows that competitiveness is particularly the result of relative prices, and thus does not indicate a sustainable competitiveness resulting from lack of added value in the export items.

Although this article reveals evidence of competitiveness, it does not compare the conditions of Turkey and rival EU countries for sustained competitiveness. Sustainability in competitiveness depends on political, legal, and macroeconomic foundations as well as microeconomic conditions for prosperity such as company operating practices and strategies, quality of inputs, infrastructure, and institutions. Competitiveness must therefore shift from comparative advantage (low-cost labor or natural resources) to competitive advantage associated with productive and distinctive products and processes.

Year-to-year variations in the $\mathrm{RCA}_{\mathrm{e}}$ indices are substantial for Turkey in regard to lemons and grapefruits. This may imply the importance of factors such as inflation, political stability, climate, and exchange rates as well as their influence on export performance. not yet being a full member of the EU and not being part of the Entry Price System. The elimination of government incentive payments and the rise of market liberalization also seem to have contributed to a steady

\section{Literature Cited}

Akgüngör, S., F. Barbaras, and N. Kumral. 2002. Competitiveness of the Turkish fruit and vegetable processing industry in the European Union market. Russ. East Eur. Finance Trade 38:34-53. 
Allen, T. 2000. Turkey and the EU, statistics in focus, European communities, C.N.: KS-NO-00005-EN-I. Eurostat C4:L-2920. Luxembourg.

Argilos, J.M. 1999. Regional diversity in the fruit sector in the European Union. Universitat Pompeu Fabra, Barcelona, Spain.

Balassa, B. 1965. Trade liberalization and revealed comparative advantage. Manchester Sch. Econ. Soc. Stud. 33:99-123.

Balassa, B. 1977. Revealed comparative advantage revisited: An analysis of relative export shares of the industrial countries, 1953-1971. Manchester Sch. Econ. Soc. Stud. 45:327-344.

Balassa, B. 1979. The changing pattern of comparative advantage in manufactured goods. Rev. Econ. Stat. 61:259-266.

Balassa, B. 1986. Comparative advantage in manufactured goods: A reappraisal. Rev. Econ. Stat. 68:315-319.

Callaert, H. 1999. Spreadsheets and statistics: The formulas and the words. Chance 12:64.

Carlqvist, L. 2008. The European Union and Turkey: The conditions of accession and the challenge of future enlargement. Faculty of Law, University of Lund, Sweden. Master's thesis.

DEFRA. 2001. Annual report 2000-2001. Horticultural Marketing Inspectorate, Department for Environment, Food \& Rural Affairs (DEFRA).

DPT (State Planning Organization). 1997. Meyvecilik, Devlet Planlama Teşkilatı, Yedinci Beş Y1 llık Kalkınma Planı ÖIK Raporu Yayın No: DPT 2469-ÖIK 516. Ankara [in Turkish].
DPT (State Planning Organization). 2000. Meyvecilik, Narenciye Raporu,Devlet Planlama Teşkilatı, 8.Beş Yıllık Kalkınma Planı, ÖIK Raporu, Ankara [in Turkish].

EC. 1973. Ankara agreement. Official Journal of the European Communities C113:2.

EC, 1996. Decision No. 1/95 of the EC-Turkey Association Council, Customs Union (96/142/EC).

EC, 1998. Trade regime for agricultural products; decision no. 1/98 of the EC-Turkey Association Council. Official Journal of the European Communities. L 86/1, Brussels.

EC, 2000. Report by the Council to the European Council on enlargement and Agenda 2000, $13241 / 9$

EC. 2001. On the state of implementation of regulation No 2200/96, on the common organization of the market in fruit and vegetables. Commission of the European Communities, Report from the Commission to the Council, Brussels.

Fertö, I. and L.J. Humbord. 2001. Competitiveness and comparative advantage in Hungarian agriculture. KTK/IE Discussion Paper 2001/6 Institute of Economics Hungarian Academy of Sciences, Budapest.

Furtun, F. 2004. Turkey: A new opportunity? Or a big mistake? Slovak Foreign Policy Affairs II:24-39.

Göetz, L. and H. Grethe. 2007. The relevance of the EU Entry Price System for imports of fresh fruits and vegetables. Georg August University of Göttingen Faculty of Agricultural Sciences Department of Agricultural Economics and Rural Development, Working Paper 07-03, ISSN 1098-9218.

Hunt, Ü. and O. Koppel. 2006. Classification and coding: Approach of different international organizations. Transport XXI:189-196.

Kayalar, O. 2006. Turkey's accession to the European Union: A two-level game analogy, Sabanc1 University, Graduate School of Arts and Social Sciences, Istanbul, Turkey. Master's Thesis.

Malorgio, G., Hertzberg, A., 2007. Competitiveness of the southern Mediterranean countries in the Italian agri-food market, 103rd EAAE Seminar, Barcelona, Spain, 23-25 Apr.

Masters, W.A. 1995. Guidelines on national comparative advantage and agricultural trade. Agricultural Policy Analysis Project, Phase III, USAID.

Richardson, D. and C. Zhang. 1999. Revealing comparative advantage: Chaotic or coherent patterns across time and sector and U.S. trading partner? National Bureau of Economic Research, Working Paper 7212, Cambridge.

Snedecor, G.W. and W.G. Cochran. 1989. Statistical methods. 8th Ed. Iowa State University Press, Ames, IA

Vollrath, T.L. 1991. Theoretical evaluation of alternative trade intensity measures of revealed comparative advantage. Weltwirtsch. Arch. 127:265-280. 